Research Article

\title{
Effects of UV Radiation on Germination, Growth, Chlorophyll Content, and Fresh and Dry Weights of Brassica rapa L. and Eruca sativa L.
}

\author{
Hussan Ara Begum ${ }^{1}$, Muhammad Hamayun ${ }^{1}$, Noor Shad ${ }^{1}$, Waqar Khan ${ }^{3}$, Jawad Ahmad ${ }^{1}$, Muhammad \\ Ezaz Hasan Khan ${ }^{2}$, David Aaron Jones ${ }^{2}$ and Kishwar Ali ${ }^{2 *}$
}

${ }^{1}$ Department of Botany, Abdul Wali Khan University Mardan, Khyber Pakbtunkhwa, Pakistan; ${ }^{2}$ School of General Education, College of the North Atlantic Qatar, Doha, Qatar; ${ }^{3}$ School of Plant Sciences, Nanjing Agriculture University, Nanjing, 210095, P.R. China.

\begin{abstract}
Due to the depletion in the ozone layer, solar UV radiation at the earth's surface is increasing, impacting economically important plants. The current study assesses the effects of UV radiation on germination, growth, chlorophyll content and fresh and dry weight of Brassica rapa L. and Eruca sativa L. Some seeds of Brassica rapa L. and Eruca sativa L. were placed in petri plates, and were exposed to UV light for 30, 60 and 120 mins daily. The source of UV light was a UV box having a UV Tube. The UV exposure on the seeds reduced the germination percentage in both species. The germination percentage in control was recorded as $19.35 \%$, while it was $18.65 \%$ in $30 \mathrm{~min}$ and $19.00 \%$ in $120 \mathrm{~min}$ exposures. Root and shoot growth of the seedlings was markedly reduced by increasing UV radiation. The shoot length was $2.40 \mathrm{~mm}$ in control, $2.75 \mathrm{~mm}$ in $30 \mathrm{~min}, 1.50 \mathrm{~mm}$ in $60 \mathrm{~min}$ and $1.60 \mathrm{~mm}$ in $120 \mathrm{~min}$ of exposure to the UV light. The root length in control was $1.38 \mathrm{~mm}, 0.90 \mathrm{~mm}$ in $30 \mathrm{~min}, 1.00 \mathrm{~mm}$ in $60 \mathrm{~min}$ and $1.17 \mathrm{~mm}$ in $120 \mathrm{~min}$ exposure. The UV irradiations affected the chlorophyll contents positively, and therefore, the total quantity of chlorophyll content increased, compared to the control. The chlorophyll content in the control was $6.90(\mu \mathrm{mol} \mathrm{m}-2)$ of leaf area while treatment showed $8.08(\mu \mathrm{mol} \mathrm{m}-2)$ in $30 \mathrm{~min}, 8.01(\mu \mathrm{mol} \mathrm{m}-2)$ in $60 \mathrm{~min}$ and $10.01(\mu \mathrm{mol}$ $\mathrm{m}-2$ ) in $120 \mathrm{~min}$ exposure. In both species, fresh and dry weights were decreased, as compared to the control set. The fresh weight of the control was $0.85 \mathrm{~g}, 0.65 \mathrm{~g}$ in $30 \mathrm{~min}, 0.78 \mathrm{~g}$ in $60 \mathrm{~min}$ and $0.61 \mathrm{~g}$ in $120 \mathrm{~min}$ exposure. The dry weight of the control was recorded to be $0.70 \mathrm{~g}, 0.60 \mathrm{~g}$ in $30 \mathrm{~min}, 0.62 \mathrm{~g}$ in $60 \mathrm{~min}$ and $0.50 \mathrm{~g}$ in $120 \mathrm{~min}$ exposure. It was concluded that ultraviolet radiation decreased the radicle and plumule lengths in Brassica rapa and Eruca sativa while increasing their chlorophyll content.

Received | January 20, 2020; Accepted | May 28, 2021; Published | July 15, 2021

*Correspondence | Kishwar Ali, School of General Education, College of the North Atlantic Qatar, Doha, Qatar; Email: kishwar.ali@cna-qatar. edu.qa

Citation | Begum, H.A., M. Hamayun, N. Shad, W. Khan, J. Ahmad, M.E.H. Khan, D.A. Jones and K. Ali. 2021. Effects of UV radiation on germination, growth, chlorophyll content, and fresh and dry weights of Brassica rapa L. and Eruca sativa L. Sarhad Journal of Agriculture, 37(3): 1016-1024.

DOI | https://dx.doi.org/10.17582/journal.sja/2021/37.3.1016.1024

Keywords | Brassica rapa L., Eruca sativa L., UV radiation, Germination, Chlorophyll content, Ozone depletion
\end{abstract}

\section{Introduction}

$\mathrm{T}$ he growth and development of plants depend upon energy obtained from the sunlight. A slight change in the wave length of light can alter the whole plant physiology and biochemistry (Schmitt and Wulff, 1993). Light waves of 400-700 nm wavelengths have greater effect on a plant's responses which cause 
alteration within the magnitude relation of UV light to influence the biomass allocation (Maliakal et al., 1999). Around the earth, the presence of the ozone layer at about $10-30 \mathrm{~km}$ above the earth surface is protecting us from harmful UV lights (Maliakal et al., 1999). One of the biggest threats to life is from the diluted stratospheric layer and the global weather alteration. Reduction in the ozone layer can cause UV light of 280-320 nm wave length to reach the earth surface. Due to thinning of ozone layer around the earth, adverse effects of UV light also increase and its intensity is multiplied by a number of topographic factors (Reddy et al., 2004). Hartley firs noted the adverse effects of UV light in 1881(Hartley, 1881; Tevini and Teramura, 1989).

Effect of UV light is high at high altitude as compared to low lying areas and it almost effect all functions of the plant starting from germination. Depletion in the ozone layer lead to enhanced the penetration of solar UV radiation to earth surface. The UV radiation reaching earth surface can affect the growth of plant. The daily UV shocks also affect the plumule and radicle length of newly growing plant (Flint and Caldwell, 2003). High intensities of UV light are destructive to all organisms including microbes (Zaman et al., 2018; Barnes et al., 1993). Paul (2001) studied species and found that UV contacts can cause alterations physiologically, morphologically, and chemically and affect it molecularly. High levels of UV light reduce chlorophyll production, soluble proteins and Rubisco in C3 plants (Nasser, 2001). As a stress factor UV light reduces growth, damages photosynthetic pigments, reduces carbon intake, and affects many other functional and hormonal systems (Fukushima and Saito, 2000; Hollosy, 2002). Due to UV light, intraspecific variations also occur in plants regarding biochemicals, wet or dry mass etc. (Kolb et al., 2001). Most plant species are very responsive to UV light while fewer are not affected by it (Teramur, 1983). UV light badly affects physiological and biochemical processes. UV treated seeds get disturbance in their protein production, exchange of gases, water distribution, hormonal and enzymatic activities (Khan et al., 2020; Hieng et al., 2004). UV treatment is harmful to plants either directly or indirectly (Horneck et al., 1995; Joshi et al., 2007). It is reported that treatment with UV causes the reduced activity of photosystem II in photosynthesis. UV exposure disturbs the stomatal opening and closing, reduces gaseous exchange lowering transpiration rate (Day and Vogelmann, 1995; Dube and Bornman, 1992).

UV light also brings alteration in cell division, hormonal imbalances with distressed nucleic acid (Mpoloka, 2008). UV light also causes a reduction in plants size, leaf size and low biomass with curled leaves (Furness et al., 1999). Members of family brassicaceae are used as pot-herb and are very important worldwide for their chemical constituents (Gomes and Rose, 2001), flavonoids and mineral nutrients (Hanaka et al., 2016; Moreno et al., 2006). Mahdavian et al. (2008) reported that UV light caused reduction in chlorophyll, anthocyanin and proline content of vegetable plants.

The present study's objective was to evaluate how UV light affects seed germination. specifically, in plants acclimatizing to cool habitat that are said to be vulnerable to high temperatures and to record changes in plants treated with UV light. In the present study seeds of some brassica species were used to screen for UV sensitivity.

\section{Materials and Methods}

Brassica rapa L. and Eruca sativa L. seeds were used in the experiment due to the importance of these plants as pot-herbs. Healthy seeds of these species were collected. Clean seeds of Brassica rapaL. and Eruca sativa L. were first sterilized with $0.5 \%$ sodium hypochlorite for two minutes, washed and soaked in distilled water for $2 \mathrm{hrs}$. Petri plates with two disks of Whatman no. 1 filter paper was used, the soaked 20 seeds were placed in the Petri plates. Seeds were placed in 7 groups of petri plates for treatment, each group with three replicates. The 1 group was of control, 2 groups were of $30 \mathrm{mins}, 2$ groups were for $60 \mathrm{mins}$ and 2 group were of $120 \mathrm{mins}$. The 6 groups were exposed for 30, 60 and 120 minutes to UV radiation daily.

There were 6 treatments with 1 control (30, 60 and $120 \mathrm{~min}$ ) each having three replicates. For germination study, petri plates were kept at room temperature. Observations on germination were recorded daily. Small amounts of distilled water were added periodically to keep the petri plates moist. Germination was recorded daily up to 15 days. On $12^{\text {th }}$ day chlorophyll pigments were determined. At the end of experiment, radicle and plumule lengths of the seedlings and their fresh and dry weights were recorded. Plumule and radical lengths were recorded 
on $14^{\text {th }}$ day of the experiment.

\section{Fresh and dry weights}

On $16^{\text {th }}$ day of seed germination, the fresh weight of each plate was find out, after finding fresh weight, then the plants were kept in oven for 48 hours to dry. On next day the dry weight was determined.

\section{Estimation of chlorophyll content}

The Two-hours soaked seeds are exposed to UV radiation for 0 (control), 30, 60 and 120 min daily till 15 days, subsequently at $12^{\text {th }}$ day chlorophyll in the leaf was determined through chlorophyll meter.

\section{Results and Discussion}

Studies demonstrated that high intensities of UV light bring several changes not only externally and internally but also disturb it chemically (Shaukat et al., 2013). The overall germination rate was significantly reduced, compared to the control group, with greater exposure to ultraviolet radiation. In Eruca sativa, the irradiation rate of ultraviolet radiation reduces significantly by 30 and 120 minutes while 60 minutes irradiation increases the germination percentage, and in Brassica rapa, the 60 and 120 minutes treatment, the germination is increased compare to 30 minutes (Table 1) but is still less than the control treatment. The results obtained in the present study showed that UV irradiation prominently affected the seed germination and chlorophyll contents of the selected plants. Brassica rapa L. and Eruca sativa L. were treated with UV light for 30, 60 and 120 mins. Germination percentage was reduced in both plants at 30 and 120 mins while at 60 mins there was little increase as compared to the 30 and 120 mins but was less than the control set.

Table 1: Percent seed germination of Brassica rapa $L$. and Eruca sativa L. exposed to UV light.

\begin{tabular}{lll}
$\begin{array}{l}\text { Treatment } \\
\text { UV-B exposure }\end{array}$ & $\begin{array}{l}\text { \% seed germination } \\
\text { of Brassica Rapa }\end{array}$ & $\begin{array}{l}\text { \% seed germination } \\
\text { of Eruca Sativa }\end{array}$ \\
\hline Control & $19.33 \pm 0.33$ & $18.77 \pm 0.33$ \\
$30 \mathrm{~min}$ & $18.77 \pm 0.33$ & $17.00 \pm 0.58$ \\
$60 \mathrm{~min}$ & $19.00 \pm 0.67$ & $19.77 \pm 0.33$ \\
$120 \mathrm{~min}$ & $19.00 \pm 0.67$ & $17.00 \pm 0.58$
\end{tabular}

Sugimoto (2013) reported that UV light suppresses the gibberellin in lettuce seeds which hindered the germination. These results were in agreement with the previous available literature (Kakani et al., 2003; Shetta, 2008; Liu and Zhong, 2009; Shetta and Areaf, 2009). Seeds radiated with UV light at germination of seed and appearance of seedling stage have more affect than other stage (Saile-Mark and Tenivi, 1997; Li et al., 2009).

\section{Radicle and plumule lengths}

The growth of the radicles in both plants (Brassica rapa L. and Eruca sativa L.) was greater in the 60 and 120 minutes treatment as compared to control and 30 min treated with ultraviolet radiation, (Table 2). In contrast, shoot growth was increased in $30 \mathrm{~min}$ in Brassica rapa while a decreased in 60 and $120 \mathrm{~min}$ exposure treatment, compared to control. Similarly decrease in shoot length was recorded Eruca sativa as compared to control set (Figure 3 and 4). The early growth stages of seeds and seedlings are very sensitive to any environmental effect including UV light (Sultan, 2000; Pliura et al., 2008). Germination of seeds irradiated with UV light and its chlorophyll content is also subjected to the plant growth stage and environmental factors (Ali et al., 2018; Kuhlmann and Muller, 2009). Previous record also showed that not only germination percentage is affected but shoot length is also decrease in some plants (Peykarestan and Seify, 2012). Plants showing less UV affect have high concentrations of Flavonoids and phenols in them (Close and McAthur, 2002; Kolb et al., 2001). Phenols are induced to accumulate in plants upon exposure to UV light as stress indicator (Kozlowska et al., 2007; Ravindran et al., 2008) and protect plants against stresses (Abreu and Mazzafera, 2005; Olenchenko and Zagoskina, 2005; Ganeva and Zozikova, 2007).

\section{Seed Germination}

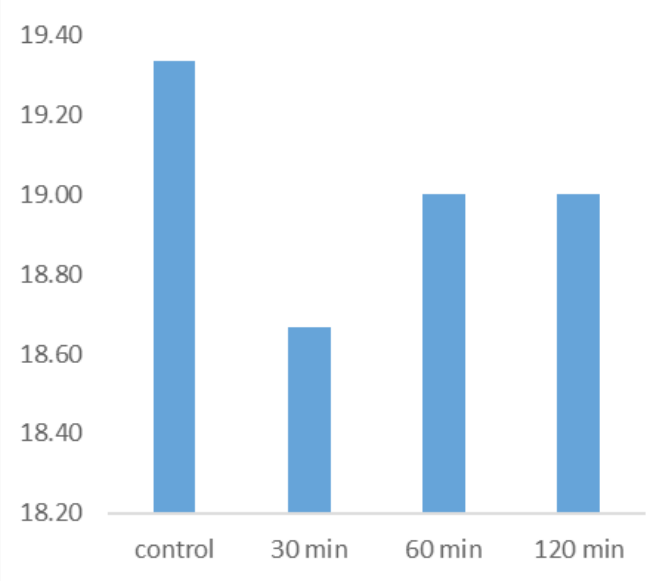

Figure 1: Seed germination of brassica rapa $L$. 
Table 2: Shoot and root length of Brassica rapa L.

\begin{tabular}{lll}
$\begin{array}{l}\text { Treatment } \\
\text { UV-B exposure }\end{array}$ & Shoot length & Root length \\
Control & $2.33 \pm 0.14$ & $1.19 \pm 0.047$ \\
$30 \mathrm{~min}$ & $2.71 \pm 0.028$ & $1.16 \pm 0.036$ \\
$60 \mathrm{~min}$ & $1.56 \pm 0.060$ & $1.54 \pm 0.056$ \\
$120 \mathrm{~min}$ & $1.74 \pm 0.043$ & $1.52 \pm 0.029$ \\
\hline
\end{tabular}

\section{Seed Germination}

Figure 2: Seed germination of Eruca sativa $L$.

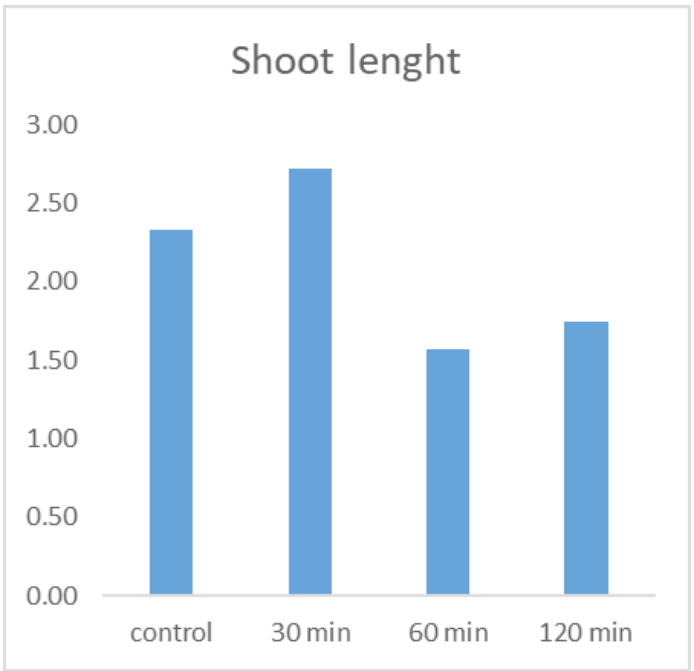

Figure 3: Shoot length of Brassica rapa $L$.

\section{Fresh and dry weight estimation}

The fresh and dry weight determines the effects of UV radiation on germination and growth. On the $16^{\text {th }}$ day of germination the fresh weight was find out. Both the Fresh and Dry weight were decreased as compared to Control. In both species (Brassica rapa L. and Eruca sativa $L$.) the Fresh and dry weight in control is more as compare to the replicates treated with UV light (30, 60 and 120min) (Table 4 and 5). Seeds are protected by flavonoids present in their seed coats (Tepfer et al., 2003). The current study showed that in all treatments the shoot and root length in both plants were affected after irradiated with UV light. Root and shoot

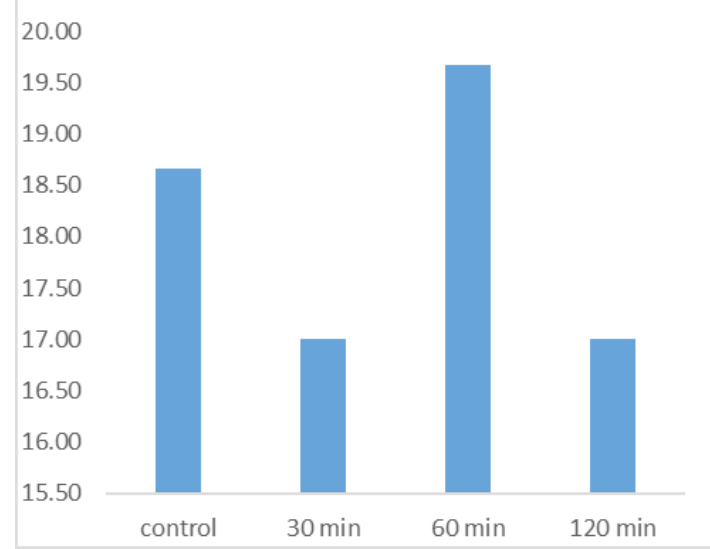

lengths of the germinating seedlings were affected by UV light in the present study. Shaukat et al. (2011) reported that growth of root and shoot was stifled by exposing to UV light. Likewise, the fresh and dry weight of the seedling which shows the growth of the seedlings also decreases. Mladin et al. (2014) reported that UV light impaired the photosystem II which results in low or even no photosynthesis that results in low biomass. UV light effect the plants but the plant's defense systems try to lessen this impact by activating its antioxidant system (Horva'th et al., 2007). UV light enhances the activity of antioxidant enzyme (Nita et al., 1996). Kondo and Kawashima (2000) also reported that UV light enhances the activity of enzymes related to antioxidants.

Table 3: Shoot and root length of Brassica rapa L. and Eurca sativa L.

$\begin{array}{lll}\begin{array}{l}\text { Treatment } \\ \text { UV-B exposure }\end{array} & \text { Shoot length } & \text { Root length } \\ \text { Control } & 2.35 \pm 0.012 & 1.39 \pm 0.012 \\ 30 \mathrm{~min} & 1.93 \pm 0.018 & 0.913 \pm 0.023 \\ 60 \mathrm{~min} & 1.51 \pm 0.015 & 1.010 \pm 0.030 \\ 120 \mathrm{~min} & 1.78 \pm 0.018 & 1.127 \pm 0.012\end{array}$

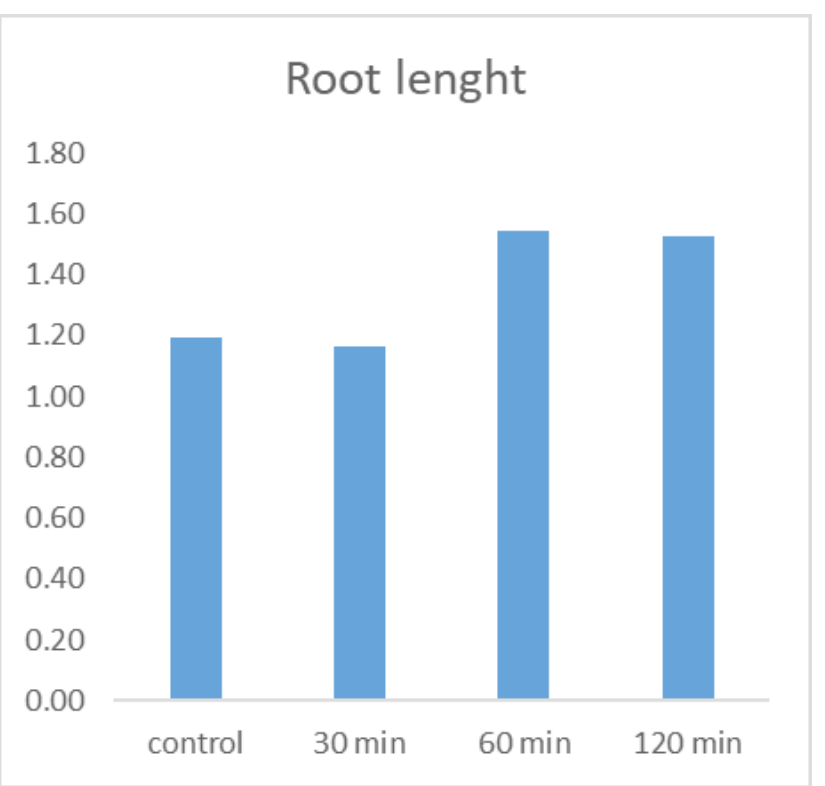

Figure 4: Root length of Brassica Rapa L.

Table 4: Effects of ultraviolet radiation on fresh and dry weight of Brassica rapa $L$.

$\begin{array}{lll}\begin{array}{l}\text { Treatment } \\ \text { UV-B exposure }\end{array} & \text { Fresh weight } & \text { Dry weight } \\ \text { Control } & 0.823 \pm 0.023 & 0.700 \pm 0.032 \\ 30 \mathrm{~min} & 0.680 \pm 0.023 & 0.590 \pm 0.032 \\ 60 \mathrm{~min} & 0.850 \pm 0.023 & 0.613 \pm 0.032 \\ 120 \mathrm{~min} & 0.623 \pm 0.023 & 0.513 \pm 0.032\end{array}$

September 2021 | Volume 37 | Issue 3 | Page 1019 
Table 5: Effect of ultraviolet radiation on Fresh and Dry weight of Eruca sativa $L$.

$\begin{array}{lcc}\begin{array}{l}\text { Treatment } \\ \text { UV-B exposure }\end{array} & \text { Fresh weight } & \text { Dry weight } \\ \text { Control } & 0.287 \pm 0.098 & 0.220 \pm 0.017 \\ 30 \mathrm{~min} & 0.197 \pm 0.026 & 0.143 \pm 0.098 \\ 60 \mathrm{~min} & 0.292 \pm 0.048 & 0.220 \pm 0.023 \\ 120 \mathrm{~min} & 0.216 \pm 0.003 & 0.177 \pm 0.003\end{array}$

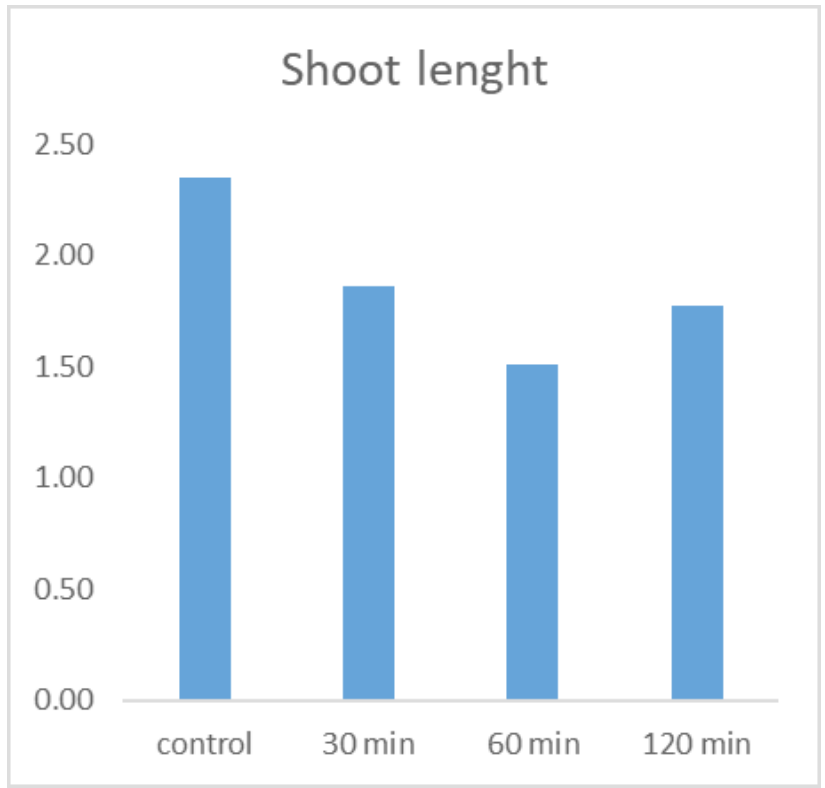

Figure 5: Shoot length of Eruca sativa $L$.

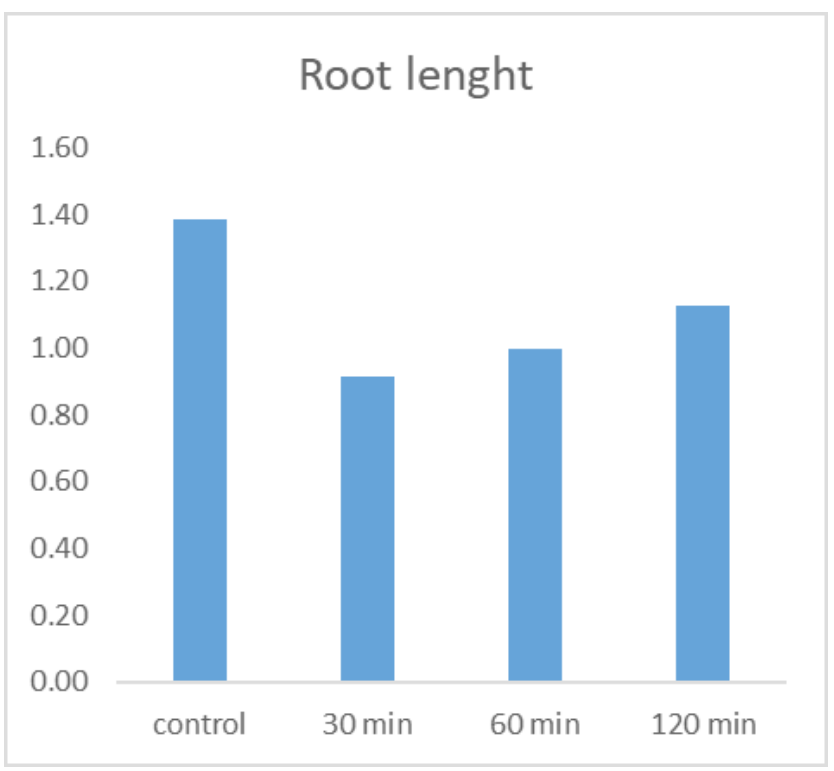

Figure 6: Root length of Eruca Sativa L.

\section{Chlorophyll contents}

Irradiation of Brassica rapa L. and Eruca sativa L. seeds to UV light, the effect of chlorophyll was comparative to the control group. The total chlorophyll pigments increased significantly as compare to the control group. The chlorophyll contents ratio increases in all treatment (30,60, and 120min) exposed to ultraviolet radiation, as compared to control (Table 6). The increase in chlorophyll content was dependent on exposure to time duration. The present study showed that the chlorophyll $\mathrm{b}$ content was increased after treatment with UV light in both plants (Figure 7 and 8). This is supported by Shaukat et al. (2011) who recorded that UV light decreased chlorophyll a content but no reduction occurs in chlorophyll $b$ content. The differences in effect on chlorophyll $a$ and $b$ contents also recorded by Gitz et al. (2004) and reported that it might be due to dissimilar pathways of both a and b chlorophyll contents (Figure 9-12). The chlorophyll a pathway either sensitive to UV shocks more than that of chlorophyll b or chlorophyll a pathway ruined prior to chlorophyll $\mathrm{b}$ pathway. The intensity and time duration also greatly affect the chlorophyll contents of the plant (Ranjbarfordoei et al., 2009). Many of the previous research support that UV light reduces the total chlorophyll content of the plant (Day and Vogelmann, 1995; Ambasht and Agarwall, 1998; Skorska, 2000; Ravindran et al., 2008).

Table 6: Effect on chlorophyll pigments exposed to $U V$ radiation.

$\begin{array}{lll}\begin{array}{l}\text { Treatment } \\ \text { UV exposure }\end{array} & \text { Brassica rapa } \mathbf{L} . & \text { Eruca sativa } \mathbf{L} . \\ \text { C0ntrol } & 9.44 \pm 0.014 & 7.33 \pm 0.082 \\ 30 \mathrm{~min} & 11.48 \pm 0.020 & 9.41 \pm 0.014 \\ 60 \mathrm{~min} & 7.63 \pm 0.014 & 8.50 \pm 0.023 \\ 120 \mathrm{~min} & 14.56 \pm 0.020 & 10.32 \pm 0.097\end{array}$

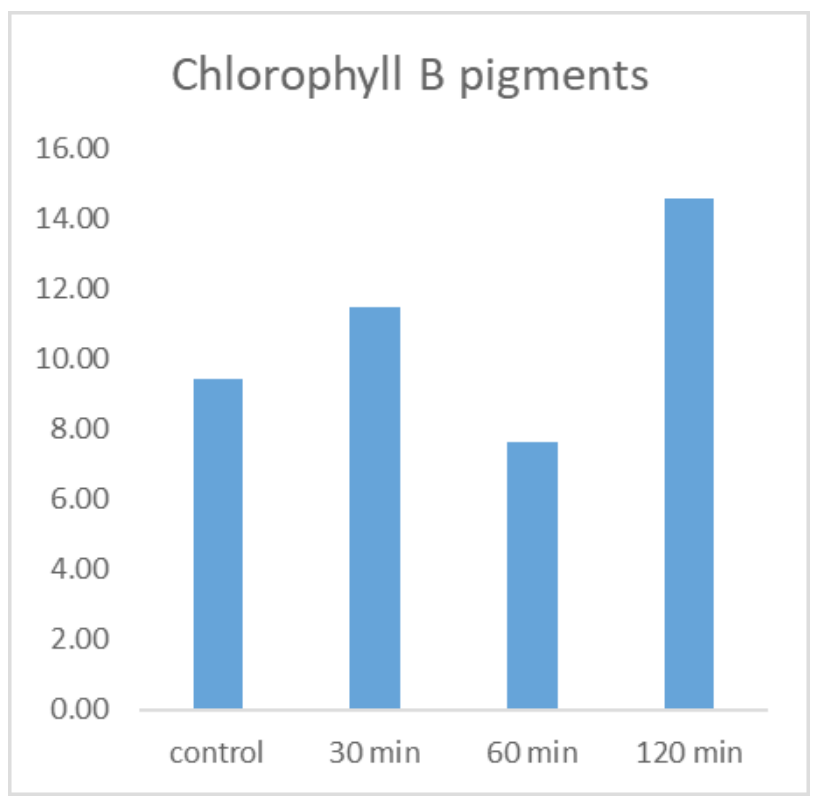

Figure 7: Effects of UV light on chlorophyll of Eruca sativa $L$. 


\section{Chlorophyll B pigments}

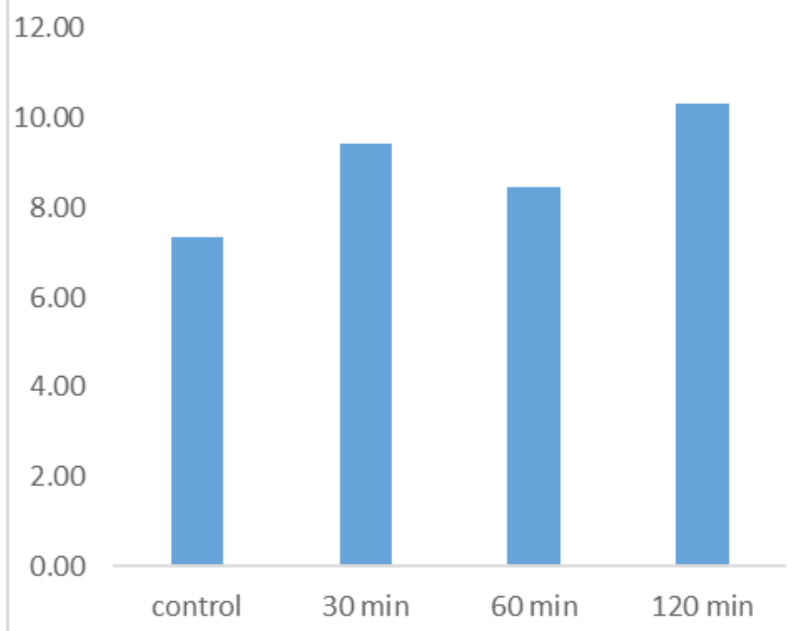

Figure 8: Effects of UV light on chlorophyll of Brassica rapa $L$.

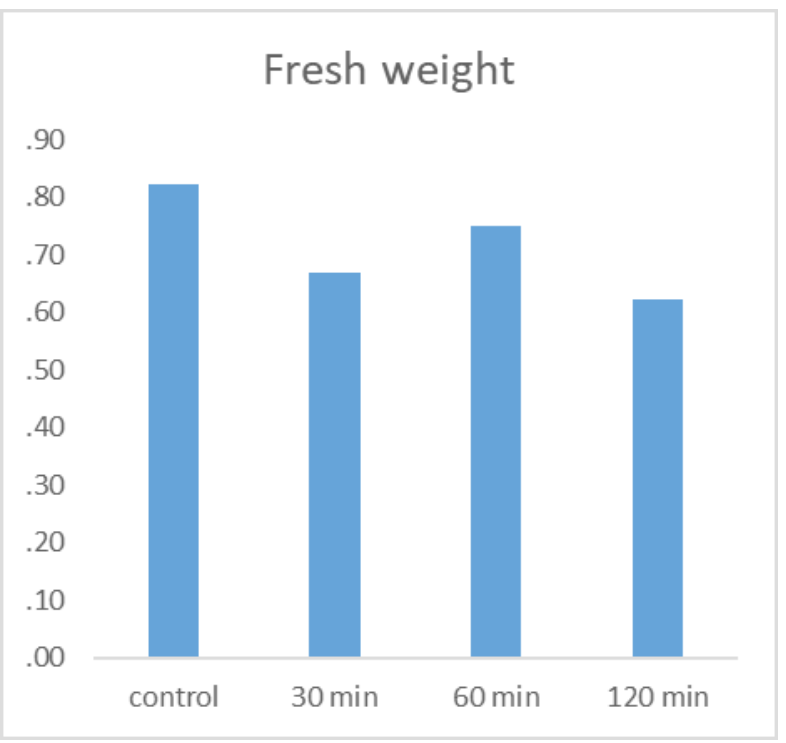

Figure 9: Fresh weight of Brassica Rapa L.

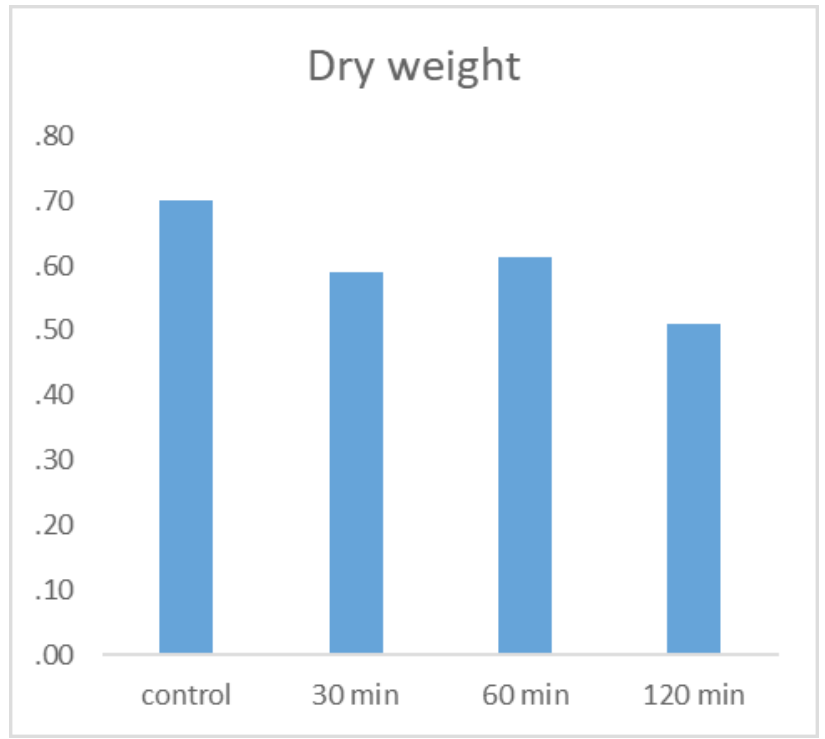

Figure 10: Dry weight of Brassica Rapa L.

\section{Fresh weight}

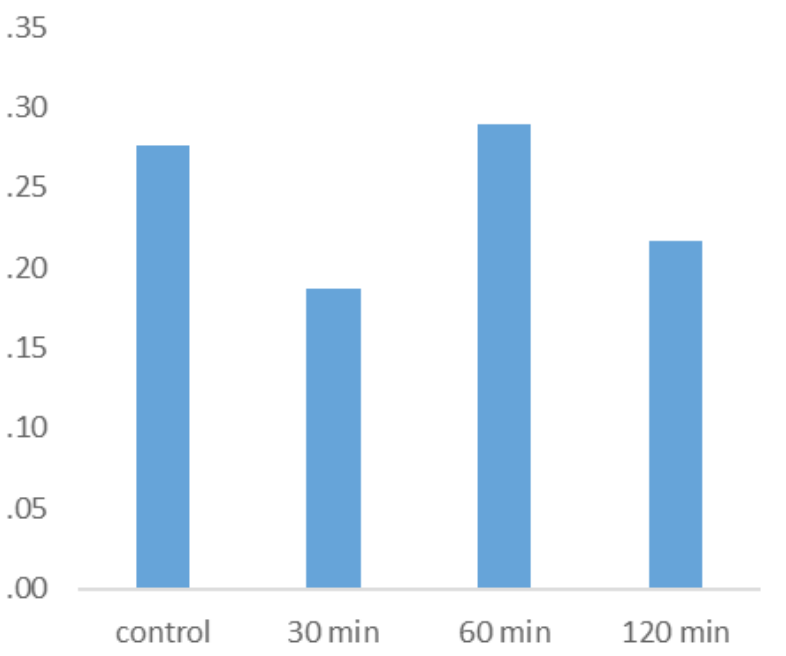

Figure 11: Effects of UV on Fresh weight of Eruca Sativa L.

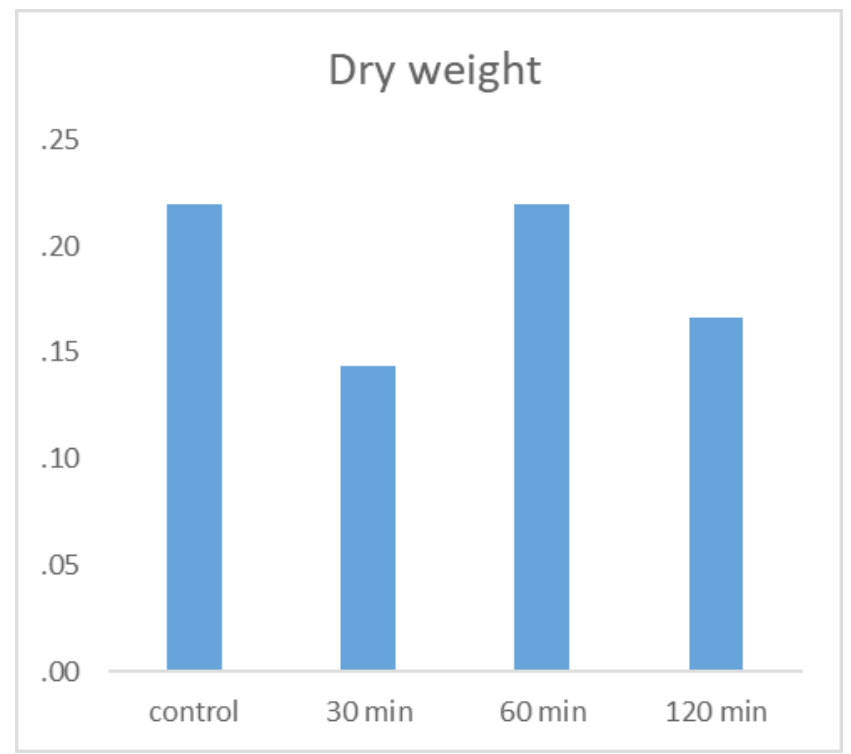

Figure 12: Effects of UV light on Dry weight of Eruca Sativa L.

\section{Conclusions and Recommendations}

Exposure of seeds to UV light significantly reduced germination percentage with decrease in speed of germination. UV exposure affected the radicle and plumule length. The shoot length decreased in all UV exposure as compared to control, the result is same in root length. UV radiation also caused curling and twisting of seedling. UV radiation suppressed the fresh and dry weight of plant, due to ultraviolet radiation the fresh and dry weight is reduced significantly in UV exposure, compare to control. Exposure to UV light can also increased the chlorophyll pigments in UV exposure as compared to control. The ultraviolet radiation reduced the plant growth, seedling and germination, but it increased the chlorophyll contents. 


\section{Novelty Statement}

The current study concludes that the ultraviolet (UV) radiations decrease crop productivity. The UV radiation reduces the overall plant growth, damages seedling and inhibits germination, but at the same time, it can increase the chlorophyll content of plants.

\section{Author's Contribution}

\section{Hussan Ara Begum and Muhammad Hamayun:} Designed the study.

Noor Shad, Waqar Khan and Jawad Ahmad: Performed the experimental work.

Muhammad Ezaz Hasan Khan, David Aaron Jones and Kishwar Ali: Wrote the manuscript.

All authors contributed to the present research equally.

\section{References}

Abreu, I.N. and P. Mazzafera. 2005. Effect of water and temperature stress on the content of active constituents of Hypericumbrasiliense Choisy. P1. Physiol. Biochem., 42: 241-248. https://doi. org/10.1016/j.plaphy.2005.01.020

Ali, K., N. Khan, I.U. Rahman, W. Khan, M. Ali, N. Uddin and M. Nisar. 2018. The ethnobotanical domain of the Swat Valley, Pakistan. J. Ethnobiol. Ethnomed., 14(1): 1-15. https:// doi.org/10.1186/s13002-018-0237-4

Ambasht,N.K.and M.Agarwal.1998.Physiological and Biochemical responses of Sorghum vulgare plants to supplemental ultraviolet-B radiation. Can. J. Bot.,76: 1290-1294. https://doi. org/10.1139/b98-137

Barnes, P.W., S.R. Maggard, S.R. Holman and B.S. Vergara. 1993. Intraspecific variation in sensitivity to UV-B radiation in rice. Crop Sci., 33: 1041-1046. https://doi.org/10.2135/ cropsci1993.0011183X003300050033x

Close, D.C. and C. McArthur. 2002. Rethinking the role of many plant phenolics protection from photodamage not herbivores. Oikos J., 99: 166-172. https://doi.org/10.1034/j.16000706.2002.990117.x

Day, T.A. and T.C. Vogelmann. 1995. Alterations in photosynthesis and pigment distribution in pea leaves following UV-B exposure. Physiol Plant., 94: 433-440. https://doi. org/10.1111/j.1399-3054.1995.tb00950.x
Dube, S.L. and J.F. Bornman. 1992. Response of spruce seedlings to simultaneous exposure to ultraviolet-B radiation and cadmium. Plant Physiol. Biochem., 30: 761-767.

Flint, S.D. and M.M. Caldwell. 2003. A biological spectral weighting function for ozone depletion, Research with higher plants. Physiol. Plant., 117(1): 137-144. https://doi. org/10.1034/j.1399-3054.2003.1170117.x

Fukushima, A. and K. Saito. 2000. Influence of UV-light on carthamin accumulation and floret elongation in a cultivar of saffron thistle (Carthamustinctorius L.). Acta Physiol. Plant., 22(2):159-162.https://doi.org/10.1007/ s11738-000-0071-9

Furness, N., M.K. Upadhyaya and D.P. Ormrod. 1999. Seedling growth and leaf surface morphological responses of three rangeland weeds to ultraviolet- $\mathrm{B}$ radiation. Weed Sci., 47: 427-434. https://doi.org/10.1017/ S0043174500092031

Ganeva, G. and E. Zozikova. 2007. Effect of increasing $\mathrm{Cu}$ concentrations on growth and content of free phenols in two lines of wheat (Triticumaestivum) with different tolerance. Gen. Appl. P1. Physiol., 33: 75-82.

Gitz, D.C., L. Liu-Gitz., J.W. McClure and A. J-Huerta. 2004. Effect of PAL inhibitor on phenolic accumulation and UV-B tolerance in Spirodelaintermedia Koch. J. Exp. Bot., 55: 919927. https://doi.org/10.1093/jxb/erh092

Gomes, M.H. and E. Rosa. 2001. Free amino acid composition in primary and secondary inflorescences of 11 broccoli (Brassica oleracea varitalica) cultivars and its variation between growing seasons. J. Sci. Food Agric., 81(3): 295-299. https://doi.org/10.1002/1097-0010(200102)8 1:3<295::AID-JSFA811>3.0.CO;2-\#

Hanaka, A., S. Dresler and R. Nurzyńska-Wierdak. 2016. Biochemical and physiological responses of Eruca sativa Mill. to selected nutrient conditions. Acta Scient. Polonorum-Hort. Cult., 15(4): 147-160.

Hartley, W.N. 1881. On the absorption of solar rays by atmospheric ozone. J. Chem. Soc. Trans., 39: 111-128. https://doi.org/10.1039/ CT8813900111

Hieng, B., K. Ugrinovic, J. Sustar-vozlic and M. Kidric. 2004. Different classes of proteases are involved in the response to drought of Phaseolus vulgaris L. cultivars differing in sensitivity. 
J. Plant Physiol., 161: 519-530. https://doi. org/10.1078/0176-1617-00956

Hollosy, F. 2002. Effects of ultraviolet radiation on plant cells. Micron, 33(2): 179-197. https://doi. org/10.1016/S0968-4328(01)00011-7

Horneck, G., U. Eschweiler, G. Reitz, J. Wehner, R. Willimek and K. Strauch. 1995. Biological response to space: Results of experiment "Exobiological unite" of ERA on EURECA I. Adv. Space Res., 16(8): 105-111. https://doi. org/10.1016/0273-1177(95)00279-N

Horvath, E., G. Szalai and T.Janda. 2007.Induction of abiotic stress tolerance by salicylic acid signaling. J. Plant Growth Regul., 26: 290-300. https://doi.org/10.1007/s00344-007-9017-4

Joshi, P.N., N.K. Ramaswamy, R.K. Iyerc, J.S. Nairb, M.K. Pradhan, S. Gartia, B. Biswal and U.C. Biswal. 2007. Partial protection of photosynthetic apparatus from UV-B induced damage by UV-A radiation, Environmental and Experimental Botany. 59:166-172. https://doi. org/10.1016/j.envexpbot.2005.11.005

Kakani, V.G., K.R. Reddy., D. Zhao and K. Sailaja. 2003. Field crop responses to ultraviolet-B radiation: A review, Agric. For. Meteorol., 120: 191-218. https://doi.org/10.1016/j. agrformet.2003.08.015

Khan, W., M. Hussain, K. Ali, M. Ali and M. Nisar. 2020. Distribution and phenotypic variation in Juglans regia L. growing in Hindu Kush ranges of Pakistan. Acta Ecol. Sin., 40(5): 363-372. https://doi.org/10.1016/j.chnaes.2020.02.009

Kolb, C.A., M.A. Käser, J. Kopecky, G. Zotz, M. Riederer and E.E. Pfündel. 2001. Effects of natural intensities of visible and ultraviolet radiation on epidermal ultraviolet screening and photosynthesis in grape leaves. Plant Physiol., 127: 863-875. https://doi.org/10.1104/ pp.010373

Kondo, N. and M. Kawashima. 2000. Enhancement of the tolerance to oxidative stress in cucumber (Cucumis satious L.) seedlings by UV-B irradiation: possible involvement of phenolic compounds and antioxidative enzymes. J. Plant Res., 113: 311-331. https://doi.org/10.1007/ PL00013863

Kozlowska, M., E. Brezezinska and M. Stobiecki. 2007. Sensitivity and accumulation of screening compounds in three conifer plants under enhanced UV-B radiation. Pol. J. Environ. Stud., 16: 823-830.
Kuhlmann, F. and C. Muller. 2009. Developmentdepended effects UV radiation exposure on broccoli plants and interaction with herbivorous insects. Environ. Exp. Bot., 66: 61-68. https:// doi.org/10.1016/j.envexpbot.2009.01.001

Li, H.Y., K.W. Pan, Q. Liu and L. Wang. 2009. Effect of enhanced UV-B on allopathic potential of Zanthoxylum bungeanum. Sci. Hortic., 119: 310-314. https://doi.org/10.1016/j. scienta.2008.08.010

Mahdavian, K., M. Ghorbanli and K.M. Kalantari. 2008. The Effects of Ultraviolet Radiation on the Contents of Chlorophyll, Flavonoid, Anthocyanin and Proline in Capsicum annuum L. Turk. J. Bot., 32(1), pp.25-33.

Maliakal, S.K., K. McDonnell, S.A. Dudley and J. Schmitt. 1999. Effects of red to far-red ratio and plant density on biomass allocation and gas exchange in Impatiens capensis. Int. J. Plant Sci., 160(4): 723-733. https://doi. org $/ 10.1086 / 314157$

Mladin, L., N. Prodan., A. Grec and S. Cosmin. 2014. The effect of uvb stress on photosynthesis in eruca sativa. Studia universitatis" Vasile goldis" Arad. Seria Stiintele Vietii. Life Sci. Ser., 24(3): 329.

Moreno, D.A., M. Carvajal., C. López-Berenguer and C. García-Viguera. 2006. Chemical and biological characterization of nutraceutical compounds of broccoli. J. Pharm. Biomed. Anal., 41(5): 1508-1522. https://doi. org/10.1016/j.jpba.2006.04.003

Mpoloka, S.W. 2008. Effects of prolonged UV-B exposure in plants. Afr. J. Biotechnol., 7(25).

Nasser, L.A., 2001. Effects of UV-B radiation on some physiological and biochemical aspects in two cultivars of barley (Hordeumvulgare L.). Egypt. J. Biol., 3(1): 97-105.

Nita, Z. and W. Orłowska-Job. 1996. Hodowlaowsanagoziarnistego w Zakładzie Doświadczalnym HAR w Strzelcach. Biul. Inst. Hod. Aklim. Roślin, 197: 141-145.

Olenchenko, N. and N. Zagoskina. 2005. Resposes of winter wheat to cold: Production of phenolic compounds and Lpenylalanine ammonia lyase activity. Appl. Biochem. Microbiol., 41: 600603. https://doi.org/10.1007/s10438-0050109-2

Paul, N.D. 2001. Plant responses to UV-B: Time to look beyond stratospheric ozone depletion. New Phytol., 150: 5-8.https://doi.org/10.1046/ 
j.1469-8137.2001.00090.x

Peykarestan, B. and M. Seify, 2012. UV irradiation effects on seed germination and growth, protein content, peroxidase and protease activity in red bean. Int. Res. J. Appl. Basic Sci., 3: 92-102.

Pliura, A., A. Baliuckiene and V. Baliukas. 2008. Phenogenetic response of silver brich populations and half-sib families to elevated ozone and ultraviolet- $B$ radiation at juvenile age. Environ. Pollut., 156: 152-161. https://doi. org/10.1016/j.envpol.2007.12.023

Ranjbarfordoei, A., P. Van Damme and R. Samson. 2009. Elevated ultraviolet-B radiation influences photosynthetic pigments and soluble carbohydrates of swe et almond [** Prunusdulcis ${ }^{* *}$ (Miller) D. Webb]. Electron. J. Environ. Agric. Food Chem., 8(11): 1077-1084.

Ravindran, K.C., A. Indrajith, V. Balkrishnan, K. Venkatesan and G. Kulanddaively. 2008. Determination of defense mechanism in Phaseolustrilobus Ait.: Seedlings treated under UV-B radiation. Afr. Crop Sci. J., 16: 111-118. https://doi.org/10.4314/acsj.v16i2.54351

Reddy, K.R., V.G. Kakanl, D. Zhao, S. Kotl and W. Gao. 2004. Interactive effects of ultraviolet radiation and temperature on cotton physiology, growth, development and hyperspectral reflectance. Photochem. Photobiol., 79(5): 416-427. https://doi.org/10.1562/2003-11-19RA.1

Saile-Mark,M. and M.Tevini.1997. Effects of solar UV-B radiation on growth, flowering and yield of central and southern European bush bean cultivars (Phaseolus vulgaris L.). Plant Ecol., 128: 115-125. https://doi.org/10.1007/97894-011-5718-6_11

Schmitt, J. and R.D. Wulff. 1993. Light spectral quality, phytochrome and plant competition. Trends Ecol. Evolut., 8(2): 47-51 https://doi.org/10.1016/01695347(93)90157-K

Shaukat, S.S., M.A. Farooq, M.F. Siddiqui and S.A.H.R.Zaidi.2013.Effect of enhanced UV-B radiation on germination, seedling growth and biochemical responses of Vigna mungo (L.) Hepper. Pak. J. Bot., 45(3): 779-785.

Shaukat, S.S., S. Zaidi and M.A. Khan. 2011. Effect of supplemental $u v-b$ radiation on germination, seedling growth, and biochemical responses of sunflower (Helianthus annuus L.). Fuuast J. Biol., 1(1): 27.
Shetta, N.D. 2008. Test the resistance to Ultraviolet irradiation and low vacuum pressure on germination of some woody tree seeds. Alex. J. Agric. Res., 53(1): 95-103.

Shetta, N.D. and I.M. Areaf. 2009. Impact of ultraviolet-c radiation on seed germination and chlorophyll concentration of some woody trees grown in Saudi Arabia. J. Agric. Environ. Sci. Alex. Univ. Egypt. 8(2): 1-17.

Skorska, E. 2000. The effect of ultraviolet-B radiation on triticale plants. Folia Univ. Agric. Stetin. Agric., 206: 249-254.

Sugimoto, K. 2013. Seed germination under UV-B irradiation. Bull. Minamikyushu Univ., 43(1): 9.

Sultan, S.E. 2000. Phenotypic plasticity for plant development, function and life history. Trends Plant Sci., 5: 537-542. https://doi.org/10.1016/ S1360-1385(00)01797-0

Tepfer, D., B. Message, L. Rémy, A. Zalar, S. Hoffman, J.M. Kenney and S. Leach. 2003. Are plant seeds terrestrial models for space travelers? $3^{\text {rd }}$ European Workshop Exo/Astro biology, Madrid Spain.

Teramura. 1983. Effects of ultraviolet-B radiation on the growth and yield of crop plants. Physiol. Plant., 58: 415- 427. https://doi. org/10.1111/j.1399-3054.1983.tb04203.x

Tevini, M. and A.H. Teramura. 1989. UV-B effects on terrestrial plants. Photochem. Photobiol., 50: 479-487. https://doi. org/10.1111/j.1751-1097.1989.tb05552.x

Zaman, S.U., K. Ali, W. Khan, M. Ali, T.Jan and M. Nisar.2018.Ethno-botanicalandgeo-referenced profiling of medicinal plants of Nawagai Valley, District Buner (Pakistan). Biosyst. Diver., 26(1). https://doi.org/10.15421/011809 